\title{
Natural Killer cells role in embryonic implantion
}

\author{
Camila Langer Marciano*, Thalia de Sousa da Silva, Murilo Andrade Nantes , Ana Gabriela Souza Gouvea , \\ Cynthia Hernandes Costa ${ }^{1}$, Renata Matuo ${ }^{1}$ \\ ${ }^{1}$ Centro Universitário Unigran Capital, Campo Grande, MS, Brasil
}

\begin{abstract}
Objective: This work aimed to elucidate the natural killer cells role during embryonic implantation process and its possible relation in abortion. Methods: A bibliographical revision was made based on scientific articles from electronic databases as Google academic, Scielo and PUBMED, and books, published in Portuguese and English, from 2003 to 2019. Results: During female reproductive cycle, NK cells act in ovulation and allows the discernment of changing from endometrium in decomposition (menstruation) to decidualization in pregnancy. In addition, NK may also influence implantation and presents a correlation with recurrent abortion. Conclusion: NK's performance in female deciduous is still controversial, so it is necessary more studies to better understand this subject.
\end{abstract}

Keywords: Natural Killer cells. Placenta. Aborted embryo.

\section{Introduction}

Assisted human reproduction is a set of techniques, that requires a multidisciplinary team, which monitors and optimizes gametes formation and viability, fertilization and embryonic development. ${ }^{1}$ In Brazil, there are currently more than 60 clinics with advanced technologies and adapted to effective achievement of all methods of fertilization. ${ }^{2}$

Alterations in reproductive system, reproductive disorders and psychological factors result in sterility and infertility diagnosis. According to World Health Organization (WHO), infertility is absence of gestation in sexually active couples and no contraceptive use methods after two years of sexual intercourse. ${ }^{2}$ This affects one in five couples, leading them to seek treatment in assisted reproduction clinics. ${ }^{3}$

In some cases, infertility has no apparent cause. ${ }^{2}$ Studies indicate immunological incompatibility between couple, which is associated with maternal-fetal tolerance during implantation. However, it has not been proven whether this relationship increases Natural Killer (NK) cells of maternal uterus. ${ }^{4}$

Differentiated NK cells frequency in endometrium aroused scientific community to an inquiry about real role of these cells. It is known their participation in first line of organism defense and it is essential for healthy life, but in female deciduous they have an antagonistic function. ${ }^{5}$ Since discovery of these cells in endometrium, researches have been done to better understand them during implantation.

About 25 years ago, British researchers found out a new kind of cell in human immune system, more specifically in uterine mucosa. At 90's they recognized as a lymphocyte type of NK lineage, being thymus-independent cells. Analysis of cells from NK family in rodents and primates decidua led to the term Uterine Natural Killer (UNK). ${ }^{6}$

In order to better understand the role of uNks, this review manuscript showed NK role during embryonic implantation, and its possible relation in abortion.

\author{
Financial support: None \\ Conflict of interest: The authors declare no conflicts of interest. \\ Submitted: July 31, 2019. \\ Accepted: July 08, 2020 \\ Study carried out at Centro Universitário Unigran Capital, Campo Grande, MS, Brazil.
}

Copyright Marciano et al. This is an Open Access article distributed under the terms of the Creative Commons Attribution License, which permits unrestricted use, distribution, and reproduction in any medium, provided the original work is properly cited. 


\section{Methods}

A bibliographic review was carried out based on the analysis of national and international scientific publications. Foremost, the selection took place through the electronic databases PubMed and SciELO. For search, keywords "Natural Killer cells", "immunity cellular", "placenta" and "aborted embryo" were employed.

As a result of this search, about 60 articles were found that contained such keywords. However, only 26 of them approached the proposed theme more completely and objectively, eight articles in foreign literature and seventeen in national literature. In general, twelve articles relate NK cells with pregnancy according to the interest of this study. However, seven of them described the behavior of defense cells during pregnancy and two of them characterized the human reproductive process.

Among these, five were used as the main basis of the research. Moffet and Shreeve, ${ }^{6}$ as also Vacca et al., ${ }^{7}$ were chosen because they extensively described uNK cells and their relationship to the endometrium. The final project of Nuñez et al. ${ }^{8}$ and the article of Jobim and Jobim, ${ }^{9}$ presented in general the function of the immune system and the performance of NK. Costa's ${ }^{10}$ thesis raised the problem and a greater understanding of the theme.

\section{Results/Discussion}

\section{Implantation}

Fecundation is essential for a new individual formation, which a male and female gametes give rise to a zygote. ${ }^{11}$ Several events are triggered by fertilization, during the course in uterine tube, from sperm penetration to first mitotic divisions, called cleavage. ${ }^{8}$

Set of cells formed from various cleavages is called morula, which undergoes morphological differentiation to blastocyst, that presents embryoblast (inner cell layer) and trophoblast (outer cell layer). Embryoblast will originate embryo and trophoblast extra-embryonic tissues. ${ }^{12}$

Approximately six days after fertilization, trophoblast cells undergo a rapid proliferation and differentiation process in syncytiotrophoblast, a multinucleated external cell mass that spreads through endometrium connective tissue and cytotrophoblast. ${ }^{12}$ Implantation depends on blastocyst's adhesion to endometrium during "implantation window." ${ }^{\text {"13,14 }}$ For a viable pregnancy, a receptive uterus and an appropriate blastocyst-endometrial interaction are needed..$^{15}$

As the progression of embryonic stages, blastocyst completely adheres to endometrial wall, simultaneously endometrial cells undergo apoptosis and surrounding uterus cells (decidua) become charged with glycogen and lipid. In decidual reaction, gaps merge and form a network, concomitantly endometrial capillaries dilate and block generating sinusoids, which corrode themselves allowing maternal blood to flow to lacunary networks. ${ }^{12}$ Studies indicate decidualization is closely linked to production of a local immunologically privileged by modifying immune system and recruiting specific cells. ${ }^{8}$

Along to deciduous cells reside UNK, T lymphocytes and macrophages. These are found at sites of implantation and modulate maternal immune response. ${ }^{8}$ According to Lima and Auler ${ }^{16}$ "Changes in the patterns of disposition of these cells in the endometrium are related to cases of recurrent implantation failure (RIF)."

\section{Gestational immunology}

Immune system is the body reaction to invaders and external factors to natural homeostasis. ${ }^{4}$ A complex cellular network interacts to discriminate "the self from the non-self" in order to destroy foreign bodies, tumor and transplanted cells. ${ }^{9}$ These pathogens produce substances called antigens, which lead to the recognition and response of the immune system. ${ }^{5}$

Immunity is divided into innate and acquired. ${ }^{5}$ Innate immunity is composed of phagocytic cells (leukocytes), NK cells, chemical mediators and epithelial barriers, which do not lack previous memory or stimulus ${ }^{17}$ Acquired immunity, consisting of $\mathrm{B}$ lymphocytes and $\mathrm{T}$, is a slow and late, but more effective protection. ${ }^{5}$

Leukocytes are cells produced in bone marrow and lymphatic tissues that have the ability to chemotaxis, displaced due to the chemical-blood-tissue concentration gradient. ${ }^{5}$ They are classified into neutrophils, monocytes, basophils, mast cells, eosinophils and macrophages. ${ }^{5,18}$

Lymphocytes are produced in bone marrow and differentiate into three main classes according to specific surface antigens (CD) presence, function and phenotype: B lymphocytes, T lymphocytes and Natural Killer (NK). 5,17 B Lymphocytes are the only ones capable of producing antibodies (immunoglobulins) and are responsible for extracellular defense. While, T lymphocytes act on intracellular protection by recognizing molecular parts of antigenic proteins bound to molecules of the major histocompatibility complex (MHC), on antigen surface presenting cells (APCs). ${ }^{5}$ 
In addition, $T$ cells divide into helper T lymphocytes (Th) and cytotoxic T lymphocytes (Tc). The first one associates with $\mathrm{B}$ lymphocytes during defense and is still differentiated in regulating $\mathrm{T}$ lymphocyte that controls immune response, and the latter eliminates infected cells. ${ }^{5}$

Cytokines are proteins that interfere with immunological and inflammatory reactions and are synthesized by macrophages, NK, and T lymphocytes. ${ }^{5}$ This designation involves several substances such as interleukins, interferons, growth factors, tumor necrosis factors, colony stimulating factors, and chemosynes. ${ }^{19}$

Unlike other lymphocytes, NK cells do not have antigen receptors, so their activation is accomplished by combining inhibitory receptors that recognize $\mathrm{MHC}$ molecules and cell surface stimulators. ${ }^{5}$

\section{Natural Killer (NK)}

Natural Killers are classified by their morphological structure, specific markers and place of origin, such as lymphocytes..$^{10}$ Because $T$ and B lymphocytes are larger and have granules in their cytoplasm, they are also called large granular lymphocytes. In addition, they present CD16 and CD56 surface antigens, but they do not manifest antibody and T-cell receptors. $5,9 \mathrm{NKs}$ belong to innate immunity and therefore act in immunological surveillance, corresponding to approximately 10 to $20 \%$ of circulating lymphocytes. ${ }^{7,9}$

These cells act in two ways: through the production of cytokines that stimulate macrophages to destroy infected cells or to recognize these cells and to apoptose them. ${ }^{5,14}$ In the first hypothesis, NK stimulate phagocytic cells through the release of interferon and (INF -y) in response to interleukin-12 (IL-12) released by macrophages during inflammation process (Figure 1)., ${ }^{5,9}$ However, infected cells identification and subsequently their programmed death is caused by $\mathrm{MHC}$ class I absence in membrane, triggering NK activation - process called missing self. 5,10

Although IL-12 is the main cytokine activator of NK, others such as interleukin-15 (IL-15), interleukin-18 (IL-18) and high concentration of interleukin-2 (IL-2) also lymphocytes. ${ }^{7,17}$

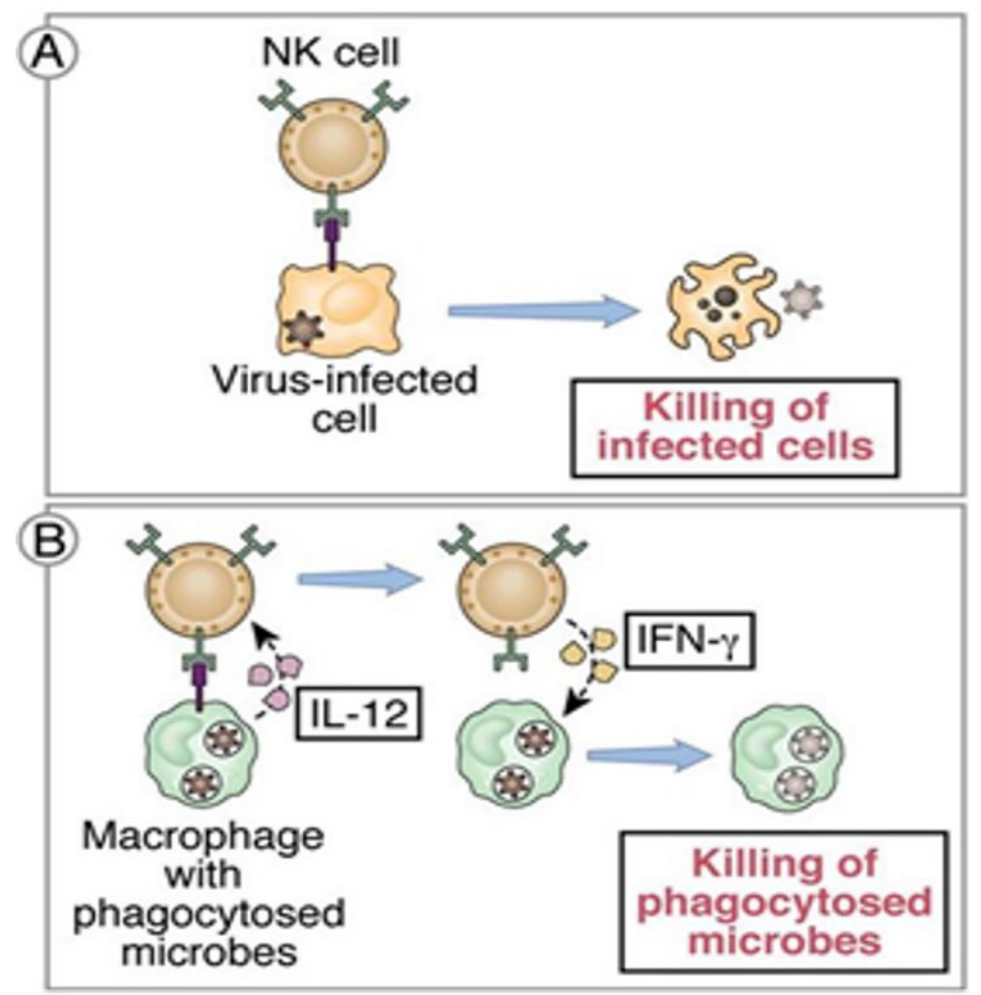

Figure 1. Functions of natural killer cells (NK). A: NK cells destroy infected host cells by intracellular microorganisms, thereby eliminating infection reservoirs. B: NK cells respond to interleukin-12 (IL-12) produced by macrophages and secrete interferon-y (IFN-y), which activates the macrophages to destroy the microorganisms that have been phagocytosed.

Source: ABBAS \& LICHTMAN, 2009. 
Activation of NK due to contact with MHC-negative target cells occurs through Killer Activating Receptors (KAR) and Killer Inhibitory Receptors (KIR). The inhibitory strains are Lectin type C, leukocyte Ig-like receptors (LIR) and killer Ig-like receptors) (KIR). Activators, however, involve several groups of molecules: CD16, NKG2D, Nkp46, Nkp30, Nkp44, among others. $5,10,14$

Immune cells in normal human uterus is composed of B, T lymphocytes, macrophages, mast cells and eosinophils. After implantation $T$ and $B$ cells become sporadic (10\%), mast cells and eosinophils become rare and there is a predominance of NK and macrophages (10 to 15\%). ${ }^{10,20,21}$

Because they are located in different body regions, NK does not exhibit the same receptor parameters. In view of this, when present in uterus are named uterine NK (UNK) and blood NK when found in peripheral blood. 21,22

\section{Uterine natural killer cells}

More than 100 years ago, literature describes the presence of granular cells in uterine mucosa of pregnant women. In vitro studies have determined that these cells belong to NK lineage. However, this name is a misconception since the ability to kill characteristic of this cellular group is negligible in UNK. ${ }^{6}$

uNKs are distinguished from those in blood mainly by CD56 receptor overexpression, promoting cytokine secretion ${ }^{23}$ and subexpression of NKG2C-E, Nkp30, Nkp44 and Nkp46 activating receptors, resulting in deficient MHC class I manifestation monitoring. ${ }^{10,14}$ Studies show that out of 10,000 transcribed genes 278 differed more than three times in uNK over blood NK, most genes were "upregulated". However, it is not yet known whether these modifications occurred in decidua or blood NK proliferation with atypical phenotypes. ${ }^{23}$

During female reproductive cycle, NK acts especially in ovulation. They are essential in discernment of changing from endometrium decomposition (menstruation) to decidualization in pregnancy. ${ }^{22}$ In case of fertilization, it proliferates and differentiate into UNK in order to embryo implantation, otherwise they die. ${ }^{23}$ In endometrium, uNK corresponds from 60 to $70 \%$ of immune cells and play role in decidua angiogenesis. ${ }^{12}$

For adequate blood supply, blood vessels remodeling in endometrium is necessary through interaction of maternal uNK and trophoblastic cells. ${ }^{24,25}$ Even though uNK levels minimize in second half of gestation, this maternal-fetal communication produces a mild systemic inflammation, as it activates region's vascular leukocytes and plasma proteins. ${ }^{23}$

For Nuñez et al. ${ }^{8}$ and Vacca "inflammatory and anti-inflammatory processes are crucial for successful implantation," according to their studies interleukin-11 a cytokine that acts on the maturation of uNK cells appears to be decreased in patients with infertility.

Blastocyst contains genetic material from father and mother proportionally and therefore is the target of maternal immune system, since it has MHC molecules different from mother. MHC polyphoric genes expressing in trophoblast are HLA-C, HLA-G and HLA-E. Theories indicate maternal-fetal immunological tolerance is due to uNK binding to trophoblast HLA-G resulting in an immunosuppressive effect of these cells cytotoxicity. ${ }^{8}$

As to Costa, ${ }^{10}$ genes like HLA-G influence woman fertility. Their hypothesis suggests a positive link between this gene and $\mathrm{UNK}$, which results in maternal-fetal tolerance.

Some researches associate elevation of NK with implantation failures and therefore therapeutic techniques with human immunoglobulin are proposed..$^{12}$ It is considered NK activity expansion and suppressor cell decrease in decidua as a recurrent spontaneous abortion (RSA) alloimmune factor. ${ }^{26}$ However, this theory is not proven and, therefore, it is not feasible to count NK cells for this purpose. ${ }^{27}$

Parham $^{23}$ as Moffett and Shreeve ${ }^{6}$ consider that uNK definition is misleading and there is no scientific validation that they cause abortion. They also claim that pharmaceutical industry uses an emotive image of maternal system destroying fetus to sell treatments without prior robust studies.

According to Parham, ${ }^{23}$ the relationship between utNK cells and trophoblast appears as cooperation, a partnership in pregnancy, rather than trench warfare between homeland advocates and fetal invaders in search of blood.

The immunological bond between the mother and the embryo is a parameter that directly influences the implantation success, therefore, the distribution of uNK cells in relation to time and space, has clinical significance in the face of failures in this implantation process. Intralipid is one of the solutions that can be used to treat recurrent abortions due to immunological factors, being an emulsion of synthetic origin composed of $10 \%$ soy oil, $1 \%$ egg phospholipids, $2 \%$ glycerin and water. This component is used through parental nutrition for patients who do not tolerate conventional nutrition and, when indicated, administration is done for the first time between 7 and 10 days before embryo transfer and again after pregnancy positivity, in situations of treatment for autoimmune causes, for cases of problems with implantation alloimmune dysfunction, the infusion is applied at intervals until the twenty-fourth week of pregnancy. ${ }^{28,29}$ 
Intralipid through its fatty acids acts as an activating ligand for receptors activated by peroxisome proliferator expressed in NK cells, leading to cytotoxic action decrease and reduced recruitment of circulating cells, improving implantation success. However, there are controversies in literature about the subject. Some studies demonstrated that this intravenous emulsion improves gestational maintenance in presence of high concentrations of NK cells, due to the ability to decrease its cytotoxicity. In addition, it is a cheap product with high availability and does not present any apparent risks to patient, nor to conditions gestation. Other studies emphasize that this methodology should not be routinely made available to patients, since its real effectiveness is doubtful because it does not have an established population profile for use and, for presenting a reasonable rate of success pregnancy and births with use of this emulsion, in addition to contesting its profitability, since its use at the lowest cost does not exceed any small benefit that it may cause, and is therefore inferior to other techniques. ${ }^{29-31}$

\section{Conclusion}

NK cells are important for immunity, since it destroys cells not compatible with normal function of organism. Differentiation into UNK is essential for gestational evolution, since they act on decidua vascularization. Maternal-fetal interaction is a complex system, involving several stages.

There is controversy in researched literature regarding on lymphocytes in women with recurrent spontaneous abortion. However, more studies are necessary since most of them were done in mice and primates.

\section{References}

1. Corrêa MCD, Costa C. Reprodução humana [Internet]. Rio de Janeiro: Projeto Ghente; 2008 [cited 2016 Nov 10]. Available from: http://www.ghente.org/

2. Machado MH. Reprodução humana assistida: aspectos éticos e jurídicos. Curitiba: Juruá; 2012.156 p.

3. Organização Mundial da Saúde. Infertility definitions and terminology. Genebra: OMS; 2016.

4. Michelon T, Silveira JG, Graudenz M, Neumann J. Pregnancy immunology. Revista da AMRIGS. 2006;50(2):145-51.

5. Abbas AK, Lichtman AH. Imunologia básica: funções e distúrbios do sistema imunológico. 3. ed. Rio de Janeiro: Elsevier; 2009.

6. Moffett A, Shreeve N. First do no harm: Uterine natural killer (NK) cells in assisted reproduction. Hum Reprod. 2015;30(7):151925. http://dx.doi.org/10.1093/humrep/dev098. PMid:25954039.

7. Vacca P, Chiossone L, Mingari MC, Moreta L. Heterogeneity of NK cells and other innate lymphoid cells in human and murine decidua. Front Immunol. 2019;10(170):1-8.

8. Nuñez AP, Wolff P, Salgado RM. O papel da interleucina 11 durante a implantação embrionária. ACIS. 2013;1(2):1-28.

9. Jobim M, Jobim LF. Natural killer cells and immune surveillance. J Pediatr (Rio J). 2008;84(Suppl 4):S58-67. http://dx.doi.org/10.1590/ S0021-75572008000500009. PMid:18830515.

10. Costa CH. Variações alélicas e combinações KIR2DL4 e HLA-G em casais submetidos a tratamento de reprodução assistida [tese de doutorado]. Paraná (BR): Universidade Federal do Paraná; 2015. 155 p.

11. Borges E Jr, Farah LMS, Cortezzi SS. Reprodução humana assistida. São Paulo: Atheneu, 2011. 352p.

12. Moore KL, Persaud TVN. Embriologia básica. 7. ed. Rio de Janeiro: Elsevier, 2008.

13. Hoffman BL, Schorge JO, Halvorson LM, Bradshaw KD, Cunningham FG. Ginecologia de Williams. São Paulo: Amgh Editora, 2012. $1402 \mathrm{p}$.

14. Jena MK, Nayak N, Chen K, Nayak NR. Role of macrophages in pregnancy and related complications. Arch Immunol Ther Exp (Warsz). 2019;67(5):295-309. http://dx.doi.org/10.1007/s00005-019-00552-7. PMid:31286151.

15. Gelmini GF, Costa CH, Bicalho MG, Roxo VMS, Schuffner A. Does exist HLA-E influence on human reproduction? Sociedade Brasileira de Reprodução Assistida SBRA. 2010;14(2):50-54.

16. Lima C, Auler JR. Injúria endometrial: mecanismos, tratamentos e eficácia. 2013. [cited 2016 Nov 10], Available from: http://www. pronascer.com.br/images/news_pn/Editorial\%20Clinica\%20Pro\%20Nascer\%20-\%20Medicina\%20Reprodutiva\%20-\%20Ed_02-01. pdf

17. Dias JA Jr. Evaluation of the percentage of natural killer cells and autoantibodies in the peripheral blood of patients with pelvic endometriosis [dissertation]. São Paulo (BR): Universidade de São Paulo; 2010. 108 p.

18. Seeley RR, Stephens TD, Tate P. Anatomia \& Fisiologia. 6. ed. Portugal: Lusociencia. 2003. 1118 p.

19. Marino FFLO. Evaluation of the levels of interleukines 12 and 18 in blood and peritoneal fluid of patients with pelvic endometriosis [dissertation]. São Paulo (BR): Universidade de São Paulo; 2006. 94 p.

20. Sarafana S, Coelho R, Neves A, Costa Trindade J. Gestational immunology. Acta Med Port. 2007;20(4):355-8. PMid:18198080.

21. Ahmadi M, Ghaebi M, Abdolmohammadi-Vahid S, Abbaspour-Aghdam S, Hamdi K, Abdollahi-Fard S, et al. NK cell frequency and cytotoxicity in correlation to pregnancy out come and response to IVIG therapy among women with recurrent pregnancy loss J Cell Physiol. 2018;234(6):9428-37. http://dx.doi.org/10.1002/jcp.27627. PMid:30317625. 
22. Moffett A, Regan L, Braude P. Natural killer cells, miscarriage, and infertility. BMJ. 2004;329(7477):329. http://dx.doi.org/10.1136/ bmj.329.7477.1283. PMid:15564263.

23. Parham P. NK Cells and trophoblasts: Partners in Pregnancy. J Exp Med. 2004;200(8):951-5. http://dx.doi.org/10.1084/jem.20041783. PMid:15492121.

24. Blois SM, Freitag N, Tirado-González I, Cheng SB, Heimesaat MM, Bereswill S, et al. NK cell-derived IL-10 is critical for DC-NK cell dialogue at the maternal-fetal interface. Sci Rep. 2017;2189(1):1-9. http://dx.doi.org/10.1038/s41598-017-02333-8. PMid:28526846.

25. Fu B, Zhou Y, Ni X, Tong X, Ding Z, Sun R, et al. Natural Killer cells promote fetal development through the secretion of growthpromoting factors. Immunity. 2017;47(6):1100-13. http://dx.doi.org/10.1016/j.immuni.2017.11.018. PMid:29262349.

26. Caetano MR, Couto E, Passini R Jr, Simoni RZ, Barini R. Gestational prognostic factors in women with recurrent spontaneous abortion. Sao Paulo Med J. 2006;124(4):181-5. http://dx.doi.org/10.1590/S1516-31802006000400002. PMid:17086297.

27. Mattar R, Traína E, Daher S. Limits in the immunological and genetical investigation of recurrent abortion. Rev Bras Ginecol Obstet. 2015; 37(3):101-4.

28. Allahbadia GN. Intralipid infusion is the current favorite of gynecologists for immunotherapy. J Obstet Gynaecol India. 2015;65(4):213-7. http://dx.doi.org/10.1007/s13224-015-0732-7. PMid:26243984.

29. Lédée N, Vasseur C, Petitbarat M, Chevrier L, Vezmar K, Dray G, et al. Intralipid may represent a new hope for patients with reproductive failures and simultaneously an over-immune endometrial activation. J Reprod Immunol. 2018;130:18-22. http:// dx.doi.org/10.1016/j.jri.2018.09.050. PMid:30286362.

30. Ehrlich R, Hull ML, Walkley J, Sacks G. Intralipid immunotherapy for repeated IVF failure. Fertility \& Reproduction. 2019;1(4):15460. http://dx.doi.org/10.1142/S2661318219500178.

31. Martini AE, Jasulaitis S, Fogg LF, Uhler ML, Hirshfeld-Cytron JE. Evaluating the utility of Intralipid infusion to improve live birth rates in patients with recurrent pregnancy loss or recurrent implantation failure. J Hum Reprod Sci. 2018;11(3):261-68.

\section{*Correspondence}

Camila Langer Marciano

Rua Afrânio Peixoto, 658, Santo Antônio

CEP: 79100-500, Campo Grande, MS, Brasil

Tel.: (67) 99228-5941

E-mail: cah_milalan@hotmail.com

\section{Author information}

CLM, TSS, MAN, AGSG -Biomedical graduated by University Center Unigran Capital; CHC -Biomedical by University Center Feevale (RS), PhD in Genetics by UFPR (2015); RM - Biologist by Londrina University State (UEL), Master by the Postgraduate Program in Genetics and Molecular Biology at the Federal University of Rio Grande do Sul (UFRGS) and PhD by the Postgraduate Program in Cellular and Molecular Biology at UFRGS, with a sandwich period at INSERM in Paris, France.

\section{Author contributions}

CLM, TSS, MAN, AGSG were responsible for the development of the research project, reading related literature and wrote the results; CHC - was the initiator of the project; RM - contributed by reviewing and supporting the group. 